\title{
Novitates ZoologicaE
}

Vol. XXXV.

JANUARY 1929.

No. 1.

\section{DESCRIPTIONS OF NEW SPECIES OF NOCTUIDAE.}

\author{
By A. E. WILEMAN, F.E.S., AND R. J. WEST.
}

THE specimens were collected by A. E. Wileman in Japan, Formosa and the Philippine Islands. All types are in the Wileman Collection. Ridgway has been used as the standard for colours. Colour terms in italies are not Ridgway's. Patagium $=$ collar-tippet. Tegula $=$ wing-base-cover.

\section{SUBFAMILY AGROTINAE.}

\section{Agrotis tamsi sp.n.}

Female.-Palpus russet mixed with fuscous black, third segment drab. Antenna with paired setae. Head : frons and vertex russet and fuscous black mixed. Thorax with hair-scales of pale drab grey and fuscous, patagium russet anteriorly, warm velvety blackish brown posteriorly, divided by a drab grey line, tegula russet tinged with blackish brown. Abdomen fuscous above and beneath with some drab grey on side, anal tuft warm buff tinged with fuscous. Pectus warm buff tinged with fuscous. Legs: foreleg drab grey outwardly, fuscous inwardly, tarsus tinged with fuscous; mid- and hindlegs fuscous with drab grey marks on tibiae, tibiae spined.—_-Forewing : a band of warm buff tinged with russet on costa ; orbicular pale drab grey tinged with russet, reniform two bars of russet tinged with fuscous, outlined with pale drab grey ; a large patch of warm velvety blackish brown in and below cell, fuscous tinged with russet along inner margin; an oblique drab grey fascia from subcosta antemedially to anal vein subbasally; antemedial fascia and claviform faintly marked; postmedial fascia blackish brown and pale drab grey, crenulate (points distad) ; subterminal area warm buff tinged with fuscous, subterminal fascia wavy, russet, commencing with a blackish brown patch on costa, termen russet; hindwing fuscous.-Underside: forewing drab grey suffused with fuscous, postmedial fascia faintly marked; hindwing drab grey suffused with fuscous, postmedial and subterminal fasciae faintly marked.

Expanse $42 \mathrm{~mm}$. (Tip to tip $40 \mathrm{~mm}$.)

Holotype. Female.-Arizan, Formosa, 7,300 ft., 23.iii.1908.

Nearest ally.-A. mandarina Leech (West China).

We have much pleasure in dedicating this species to Mr. W. H. T. Tams, of the Entomological Department, British Museum (Natural History), from whom we have received great assistance in determining and naming new species from Formosa, Japan and the Philippine Islands. 


\section{Subfamily CUCULLIINAE.}

\section{Cosmia citrago Linn. subsp. japonago subsp.n.}

Male.-Palpus buff-yellow. Antenna dentate fasciculate. Head: frons and vertex buff-yellow. Thorax, patagium and tegula buff-yellow tinged with orange posteriorly. Abdomen buff-yellow above and beneath, anal tuft buffyellow tinged with orange. Pectus light buff. Legs buff-yellow.-Forewing buff-yellow irrorated with orange; subbasal fascia wavy, orange; antemedial fascia orange, oblique to subcosta, sharply angled outwardly and oblique to inner margin ; orbicular and reniform faintly outlined with orange ; an oblique fuscous fascia slightly excurved, from costa medially to inner margin antemedially; postmedial fascia a thin fuscous line excurved to vein 2 , then incurved to inner margin; fringe on inner margin and termen fuscous; hindwing cartridge-buff tinged with buff-yellow on veins and inner margin.-Underside: fore- and hind-wings cartridge-buff tinged with buff-yellow.

Expanse $36 \mathrm{~mm}$. (Tip to tip $35 \mathrm{~mm}$.)

Holotype. Male.-Junsai Numa, prov. Oshima, Hokkaidō I. (Yezo), Japan (plains), 13. viii. 1903.

The antenna of subspecies $C$. citrago citrago Linnaeus from Europe is bifasciculate, whilst that of subspecies $C$. citrago japonago is biserrate-fasciculate with sessile fascicles of cilia. Mr. W. H. T. Tams has been kind enough to examine the genitalia of the two subspecies and has discovered that they differ. The harpe in $C$. citrago citrago is club-shaped, but that of $C$. citrago japonago is acuminate.

This seems to be the first subspecies of $C$. citrago so far discovered out of Europe, and is quite new to Japan.

\section{SubFamily ACRONYCTINAE.}

\section{Trachea lucipara sp.n.}

Male.-Palpus upturned, smoothly scaled with fuscous black and russet, tinged with dark perilla purple. Antenna finely ciliated, with paired setae. Head : frons and vertex russet tinged with dark perilla purple. Thorax russet, patagium and tegula russet mixed with fuscous black tinged with dark perilla purple. Abdomen russet tinged with dark perilla purple, with warm buff hairscales faintly tinged with purple covering the basal segments, venter russet tinged with dark perilla purple, anal tuft light buff tinged with light salmon-orange. Pectus russet tinged with dark perilla purple. Legs : tibiae fuscous black mixed with cartridge buff tinged with dark perilla purple, tarsal segments fuscous black, light salmon-orange at joints.___- Forewing hessian brown ; subbasal fascia consisting of two wavy fuscous black lines to median fold; antemedial fascia two faintly marked fuscous black excurved lines; claviform faintly marked with fuscous black, orbicular outlined with fuscous black and warm buff, reniform outlined with fuscous black on basal side, and a warm buff patch on distal side ; postmedial fascia faintly outlined with fuscous, excurved to vein 4 , then slightly incurved to inner margin; three warm buff spots on costa near apex, and a warm buff patch suffused with hessian brown at apex ; subterminal fascia sagittate (points basad); cilia a mixture of hessian brown and fuscous; underside light buff suffused with hessian brown on upper half, two fuscous patches, one 
on costa near base, the other occupying cell ; postmedial and subterminal fasciae fuscous, and a triangular fuscous patch at the commencement of subterminal near apex, this patch is outlined with light buff and has in it two light buff points on costa.- Hindwing light buff suffused with hessian brown, faint postmedial and subterminal fasciae; underside light buff tinged with hessian brown on upper half, postmedial and subterminal fasciae fuscous, fuscous spot on discocellulars.

Expanse $36 \mathrm{~mm}$. (Tip to tip $32 \mathrm{~mm}$.)

Holotype. Male.-Baguio, subprov. Benguet, Luzon I., Philippines, 5,000 ft., 2.vi. 1913.

Nearest ally.-T. consummata Wlk. (type from Ceylon).

\section{Trachea securifera sp.n.}

Male.-Palpus wood-brown mixed with fuscous. Antenna ciliated, with paired setae, shaft fuscous, at basal third each segment ringed with wood-brown. Head : frons warm buff with dark perilla purple band just below the bases of antennae, vertex wood-brown. Thorax covered with wood-brown scales tipped with pale olive-buff, patagium natal brown anteriorly, bordered with wood-brown posteriorly, tegula brownish drab. Abdomen brownish drab above and beneath, and clothed with hairs on sides, anal tuft brownish drab. Pectus light buff tinged with purple drab. Legs brownish drab, tarsal segments fuscous, tarsal joints vinaceous buff.___ Forewing verona-brown, all fasciae wavy, and outlined with fuscous black, orbicular and claviform incompletely outlined with fuscous black; reniform bordered by triangular fuscous black patch basad, and pale gull-grey patch distad, extending to costa ; three drab grey spots on costa between postmedial and apex ; pale gull-grey points on veins postmedially, and a sprinkling of pale gull-grey scales on anal vein between antemedial and postmedial fasciae, a fuscous black streak from postmedial to termen between veins 2 and 3, with a brownish drab dot in its centre; underside light buff tinged with purple, slightly opalescent near inner margin, fuscous postmedial and subterminal fasciae, with light buff between at costa, two light buff spots on costa near apex.- Hind-wing light buff suffused with fuscous; underside light buff suffused with purple on upper half, fuscous on discocellulars, and fuscous postmedial and subterminal fasciae.

Expanse $34 \mathrm{~mm}$. (Tip to tip $33 \mathrm{~mm}$.)

Holotype. Male.-Haights' Place, Pauai, subprov. Benguet, Luzon I., Philippines, 7,000 ft., 9.xi.1912.

Paratype. Male.-Haights' Place, Pauai, subprov. Benguet, Luzon I., $7,000 \mathrm{ft} ., 8 . x i .1912$.

Nearest ally.-T. consummata Wlk. (type from Ceylon).

\section{Trachea peridela sp.n.}

Female.-Palpus wood-brown mixed with warm sepia. Antenna ciliated, with paired setae. Head : frons warm buff with natal brown just below bases of antennae, vertex warm buff and natal brown mixed. Thorax natal brown tipped with warm buff, patagium natal brown with a line of light buff across the centre, tegula natal brown mixed with a few light buff scales. Abdomen warm 
buff tinged with brownish drab, brownish drab dorsal crest, venter brownish drab. Pectus light buff tinged with natal brown; legs brownish drab mixed with warm sepia, tarsi ringed at the joints with vinaceous buff.-_- Forewing natal brown to warm sepia, subbasal fascia warm buff edged with velvety blackish brown, antemedial fascia wavy, ill-defined warm buff outwardly edged with velvety blackish brown; orbicular outlined with velvety blackish brown, a small pearl grey spot at basal edge ; reniform outlined with velvety blackish brown, bordered by pearl-grey patch distally, with smaller spots above and below this patch; claviform outlined with velvety blackish brown; postmedial fascia warm buff edged with velvety blackish brown (the distal edge having some small pearl-grey spots), excurved from veins 5 to 2 , slightly incurved to inner margin ; a sprinkling of pearl-grey scales on anal vein between antemedial and postmedial fasciae, four velvety blackish brown streaks from postmedial to termen, between veins 2 and 6 , through which a broken warm buff subterminal line passes, breaking up the streaks into sagittate marks ; underside light buff tinged with vinaceous russet, glossy, a fuscous spot on discocellulars, a straight (except at costa) fuscous postmedial band, and a faintly marked subterminal band.- Hindwing light buff suffused with fuscous; underside light buff, upper third irrorated, outer third suffused, with warm sepia to fuscous, and tinged with vinaceous russet, with a fuscous spot on discocellulars, a wavy fuscous postmedial band, and a diffuse fuscous subterminal band.

Expanse $42 \mathrm{~mm}$. (Tip to tip $39 \mathrm{~mm}$.)

Holotype. Female.-Haights' Place, Pauai, subprov. Benguet, Luzon I., Philippines, 7,000 ft., 20.xi. 1912.

Paratype. Female.-Haights' Place, Pauai, subprov. Benguet, Luzon I., Philippines, 7,000 ft., 12.i.1912.

Nearest ally.-T. consummata Wlk. (type from Ceylon).

\section{Trachea discisignata sp.n.}

Male.-Palpus light buff mixed with wood-brown and fuscous. Antenna ciliated, with paired setae. Head: frons and vertex warm buff tinged with wood-brown. Thorax warm buff, patagium warm buff tinged with wood-brown, a fuscous line across the middle, tegula warm buff tinged with wood-brown posteriorly, with a few fuscous black hair-scales at middle. Abdomen warm buff tinged with wood-brown, venter warm buff, anal tuft light ochraceous buff. Pectus warm buff. Legs warm buff tinged with wood-brown, tarsal segments fuscous, joints warm buff.___Forewing warm buff shaded with wood-brown, all fasciae wavy, faintly outlined with fuscous, orbicular finely outlined with fuscous black, reniform outlined with fuscous black, filled with white and fuscous to fuscous black, claviform wide, filled with fuscous and outlined with fuscous black; an oblique fuscous band from costa medially, to termen near tornus, slightly down-curved and broken in middle below cell, cilia warm buff with fuscous interneurally ; underside cartridge buff tinged with cinnamon drab, slightly opalescent along inner margin, fuscous on discocellulars, postmedial and subterminal fasciae faintly marked with fuscous, cartridge buff between at costa, faint triangular fuscous patch in which are two eartridge spots on costa at commencement of subterminal.—Hindwing cartridge buff, veins fuscous, fuscous irroration in subterminal area, cilia cartridge buff; underside cartridge buff, wood-brown 
on discocellulars, postmedial and subterminal fasciae faintly indicated in woodbrown.

Expanse $38 \mathrm{~mm}$. (Tip to tip $36 \mathrm{~mm}$.)

Holotype. Male.-Haights' Place, Pauai, subprov. Benguet, Luzon I., Philippines, 7,000 ft., 12.i.1912; and three paratypes, all males.

Nearest ally.-T. consummata Wlk. (type from Ceylon).

\section{Data rhabdochlaena sp.n.}

Male.-Palpus cartridge-buff, chocolate above. Antenna minutely ciliated, with paired setae, the latter hardly longer than the cilia. Head: frons and vertex covered with a mixture of cartridge-buff and chocolate. Thorax with patagium and tegula, wood-brown mixed with chocolate. Abdomen cinnamon buff, with chocolate dorsal crests on basal segments, venter shell-pink streaked with wood-brown and chocolate, anal tuft wood-brown tinged with chocolate. Pectus cinnamon-buff. Legs wood-brown tinged with chocolate.-Forewing wood-brown overlaid with velvety warm blackish brown to velvety blackish brown, the veins streaked with drab grey; subbasal fascia white, in two outward curves to median fold; antemedial fascia white edged with fuscous black, excurved to vein 1, then sharply curved back to inner margin; postmedial fascia white inwardly edged with fuscous black, wavy, excurved to vein 4, then slightly oblique to inner margin; subterminal a white zigzag line bordered by fuscous black to vein 5 , sharply dentate to termen at veins 4 and 3 , then wavy to inner margin ; orbicular marked by a down-curved white line tinged with shell-pink, the area inside the curve filled with fuscous black, reniform marked by oblique white bars tinged with shell-pink, fuscous between ; a white spot in angle formed by veins 4 and 5 , with a smaller white spot below, between veins 3 and 4 ; underside warm buff suffused with wood-brown, postmedial band narrow, fuscous, crenulate ; a subterminal line of pale drab-grey dashes.-Hindwing cinnamonbuff, with wide border of army-brown on termen ; underside warm buff, bordered along costa and termen with a mixture of wood-brown and shell-pink with chocolate irroration, fuscous on discocellulars, postmedial line crenulate, fuscous.

Expanse $38 \mathrm{~mm}$. (Tip to tip $35 \mathrm{~mm}$.)

Female.-Similar to male.

Expanse $38 \mathrm{~mm}$. (Tip to tip $36 \mathrm{~mm}$.)

Holotype. Male.-Klondyke, subprov. Benguet, Luzon I., Philippines, $800 \mathrm{ft}$., 7 .iv. 1912.

Allotype. Female.-Klondyke, subprov. Benguet, Luzon I., Philippines, $800 \mathrm{ft}$., 8.iv. 1912.

Paratype. Two Males.-Klondyke, subprov. Benguet, Luzon I., Philippines, $800 \mathrm{ft} ., 22$.iii and 7.iv. 1912.

Nearest ally. -D. callopistrioides Moore (India).

\section{Callopistria tytha sp.n.}

Female.-Palpus wood-brown mixed with pale drab-grey. Antenna minutely ciliated, with very short paired setae. Head : frons and vertex chocolate and pale drab-grey mixed, occiput warm buff. Thorax: patagium drab grey anteriorly, chocolate posteriorly, tegula warm buff tinged with wood-brown. Abdomen drab grey, venter pale drab-grey with chocolate irrorations and streaks, 
anal tuft warm buff tinged with ochraceous orange. Pectus pale drab-grey. Legs: pale drab-grey, foreleg pale drab-grey streaked with chocolate, tarsi wood-brown._- Forewing basal area chocolate, medial area russet shaded with chocolate, subterminal area chocolate, veins light drab; an oblique pale drabgrey fascia from costa at one-third, to median nervure subbasally; an oblique fascia of two white lines with chocolate between, from costa slightly beyond middle to inner margin at one-third a shorter oblique fascia of two white lines with chocolate between from costa at a third, joining the previous fascia at right angles, on median nervure; orbicular irregular, outlined with white, filled with chocolate ; reniform: oblique white bars, between which is a small elongate patch of cameo pink; a faint pale drab-grey postmedial fascia excurved to vein 2 , then incurved to inner margin; a narrow subterminal zigzag white fascia from costa to vein 5 , then pronounced and oblique to termen at vein 4 , incurved to inner margin ; a fine white fascia near termen, termen light drab, cilia fuscous ; underside drab, drab-grey along costa, subterminal fascia of pale drab-grey dashes, drab-grey on inner margin, a pale drab-grey patch on costa postmedially, and two pale drab-grey points on costa near apex.-Hindwing upperside drab-grey suffused with fuscous, fringe cartridge buff with a fuscous line running through it ; underside pale drab-grey with scattered fuscous scales below costa, a fuscous lunule on discocellulars, fuscous postmedial and subterminal fasciae, marked strongly at costa, the remainder faint.

Expanse $24 \mathrm{~mm}$. (Tip to tip $23 \mathrm{~mm}$.)

Holotype. Female.-Klondyke, subprov. Benguet, Luzon I., Philippines, $800 \mathrm{ft} ., 17$.iv. 1912.

Nearest ally.-E. aethiops Butl. (type from Japan).

\section{Chytonix olethria sp.n.}

Male.-Head and antennae missing (in type). Thorax, patagium and tegula drab mixed with fuscous black. Abdomen drab mixed with fuscous black above and beneath, anal tuft drab. Pectus and legs drab.-Forewing drab, a large patch of fuscous black at base of wing, as far as antemedial on costa, and postmedial on inner margin, the distal edge oblique from costa to median fold, parallel with inner margin to postmedial ; a white quadrate spot at intersection of postmedial and median fold ; orbicular and reniform lightly outlined with fuscous black; a triangular fuscous black patch on costa at middle, the point touching orbicular; postmedial a thin fuscous black excurved line, subterminal area suffused with fuscous black; underside drab.-Hindwing: upperside fuscous, underside drab.

Expanse $24 \mathrm{~mm}$. (Tip to tip $22 \mathrm{~mm}$.)

Holotype. Male.-Samaji, prov. Awa, Shikoku I., Japan, 22.ix.1896.

Nearest ally.-C. albipuncta Hmpsn. (China).

\section{Athetis implacata sp.n.}

Female.-Palpus light buff, natal brown outwardly and above. Head: frons and vertex light buff tinged with natal brown. Thorax, patagium and tegula light buff tinged with natal brown. Abdomen natal brown above and below, anal tuft warm buff tinged with natal brown. Pectus light buff tinged with natal brown. Legs : foreleg natal brown, joints of tarsal segments light 
buff ; other legs light buff tinged with natal brown, tarsal segments natal brown, joints light buff._- Forewing : ground-colour natal brown, basal part of wing up to orbicular suffused with vinaceous buff; subbasal, antemedial and postmedial fasciae indicated by a sprinkling of bone-brown scales; orbicular circular, reniform oval, both large, outlined with light buff edged with snuff-brown ; a suffusion of vinaceous buff extending on each side of postmedial fascia; subterminal fascia a light buff line edged with snuff-brown, slightly excurved; interneural bonebrown spots on termen. Hindwing light buff tinged with natal brown, fringe light buff with natal brown line through centre._- Underside : forewing light buff tinged with natal brown, postmedial and subterminal fasciae natal brown ; hindwing cartridge-buff irrorated with natal brown on upper half, a natal brown spot on discocellulars, postmedial fascia natal brown.

Expanse $38 \mathrm{~mm}$. (Tip to tip $37 \mathrm{~mm}$.)

Holotype. Female.-Arizan, Formosa, 7,500 ft., 23. viii. 1908.

Nearest ally.-A. placata Leech (China).

\section{Athetis multilinea sp.n.}

Male.-Palpus thickly scaled, second segment fuscous black, distal third pale drab-grey, third segment pale drab-grey mixed with fuscous black. Antenna minutely ciliated. Head: frons and vertex pale drab-grey mixed with fuscous. Thorax, patagium and tegula pale drab-grey mixed with fuscous. Abdomen pale drab-grey tinged with fuscous above and beneath, anal tuft drab-grey tinged with warm buff. Pectus pale drab-grey. Legs : foreleg coxa and femur pale drabgrey, fuscous above, tibia pale drab-grey speckled with fuscous, tarsal segments fuscous, joints pale drab-grey ; other legs pale drab-grey speckled with fuscous, tarsal segments fuscous, joints pale drab-grey.-Forewing: ground-colour pale drab-grey, subbasal fascia fuscous, excurved to median nervure, antemedial fascia wavy, consisting of two fuscous lines separated by ground-colour ; irregularly crenate fuscous medial shade, orbicular indicated by a fuscous dot, reniform a small warm buff patch outlined with fuscous and fuscous black; postmedial fascia fuscous, crenulate, excurved; subterminal area suffused with fuscous in which the fascia is indicated by a wavy shade, interneural spots of fuscous black on termen, fringe pale drab-grey suffused with fuscous; underside drab, mixed with pale drab-grey along costa, a faint fuscous lunule on discocellulars, and faint postmedial fascia._- Hindwing pale drab-grey, tinged with fuscous on termen and inner margin; underside pale drab-grey, speckled with fuscous below costa, a fuscous spot on discocellulars and fuscous fascia from vein 6 .

Expanse $32 \mathrm{~mm}$. (Tip to tip $30 \mathrm{~mm}$.)

Holotype. Male.-Baguio, subprov. Benguet, Luzon I., Philippines, $5,000 \mathrm{ft}$., 28. iii. 1912.

Paratypes. Two Males.-Baguio, subprov. Benguet, Luzon I., Philippines, $5,000 \mathrm{ft}$., 9. vii and 16.xii.1912.

Nearest ally.-A. bremusa Swinh. (India, Ceylon, Formosa).

\section{Athetis punctirena sp.n.}

Female.-Palpus army-brown. Antenna with paired setae. Head: frons and vertex army-brown. Thorax, patagium and tegula army-brown. Abdomen fuscous, venter light buff tinged with fuscous. Pectus light buff tinged with 
fuscous. Legs: foreleg light buff, fuscous above, tarsal segments fuscous, joints light buff; other legs light buff speckled with fuscous, tarsal segments fuscous, joints light buff._—_Forewing army-brown, basal half tinged with vinaceous brown; subbasal fascia faintly marked, excurved to median fold; antemedial fascia a narrow slightly excurved fuscous line; orbicular indicated by a fuscous dot, reniform indicated by a broken outline of white dots, and a warm buff spot on distal side; a fuscous shade medially, postmedial fascia a narrow wavy fuscous line; subterminal fascia a wavy fuscous shade, terminal line light buff with white dots on veins, fringe fuscous. Hindwing cartridge buff tinged with fuscous on veins, subterminal area and along inner margin, fringe light buff.___ Underside : forewing light buff irrorated with fuscous below costa, remainder tinged with fuscous, fuscous lunule on discocellulars; hindwing cartridge-buff irrorated with fuscous below costa, on postmedial fascia and termen, fuscous lunule on discocellulars.

Expanse $30 \mathrm{~mm}$. (Tip to tip $28 \mathrm{~mm}$.)

Holotype. Female.-Rantaizan, Formosa, 7,500 ft., 9.v.1909.

Nearest ally.-A. placida Moore (India, Ceylon, Formosa).

\section{Athetis triangulata sp.n.}

Male.-Palpus pale drab-grey, hair-brown outwardly on basal half of second segment. Antenna minutely ciliated, with paired setae. Head: frons and vertex pale drab grey. Thorax drab, patagium and tegula drab-grey tinged with drab. Abdomen drab-grey tinged with fuscous above and beneath, anal tuft pinkish buff. Pectus pale drab-grey. Legs drab-grey. Forewing drab-grey irrorated with fuscous, fuscous spots on costa subbasally and antemedially; fuscous spot at base of cell, orbicular indicated by a fuscous black dot, reniform by a faint warm buff spot preceded by a few fuscous black scales; a faint fuscous medial shade, a postmedial series of fuscous dots; subterminal broken row of fuscous spots, those between veins 4 and 5, 5 and 6 , are larger and merged together forming a conspicuous triangular patch (point basad); underside drabgrey.-Hindwing: upperside and underside whitish, underside with a fuscous lunule, fuscous irroration at apex.

Expanse $28 \mathrm{~mm}$. (Tip to tip $26 \mathrm{~mm}$.)

Female.-Similar to male.

Expanse $28 \mathrm{~mm}$. (Tip to tip $27 \mathrm{~mm}$.)

Holotype. Male.-Palali, subprov. Benguet, Luzon I., Philippines, 2,000 ft., 24. xii. 1912.

Allotype. Female.-Sapiangao, subprov. Benguet, Luzon I., Philippines $5,500 \mathrm{ft} ., 15$. xii. 1912 .

Nearest ally.-A. bimacula Wlk. (type from Borneo).

\section{Athetis plumbescens sp.n.}

Male-Palpus deep mouse-grey, a little pale drab-grey beneath and at junction of second and third segments. Antenna serrate fasciculate, with paired setae. Head: frons fuscous and drab-grey mixed, with a warm buff patch on lower half, vertex fuscous and drab-grey mixed. Thorax drab-grey, patagium fuscous and drab-grey mixed. Abdomen hair-brown, venter drab-grey, anal tuft light buff. Pectus light buff. Legs pale drab-grey and fuscous mixed.- 
Forewing: ground-colour drab-grey, all fascia faintly marked in fuscous and accentuated with fuscous black, subbasal wavy, apparently not extending beyond median nervure, antemedial wavy, medial shade excurved at median nervure, postmedial crenulate, excurved to vein 2 , incurved to inner margin, subterminal wavy with broken line of dots, two spots between veins 4 and 5,5 and 6 , being much larger than the dots; orbicular indicated by a fuscous dot, reniform by a small light buff patch, a few fuscous scales, and a whitish dot at upper angle and another at lower angle of cell ; underside drab-grey, pale drab-grey and irrorated with fuscous along costa, paler along inner margin, an indistinct lunule on discocellulars, postmedial and subterminal fasciae faintly indicated in fuscous.

Hindwing semi-hyaline pale drab-grey, veins, termen and inner margin tinged with fuscous; underside pale drab-grey with scattered fuscous scales below costa, a faint lunule on discocellulars, subterminal fascia indicated by faint fuscous streaks on veins.

Expanse $37 \mathrm{~mm}$. (Tip to tip $35 \mathrm{~mm}$.)

Holotype. Male.-Haights' Place, Pauai, subprov. Benguet, Luzon I., Philippines, 7,000 ft., 30.xi. 1912.

Nearest ally.-A. bimacula Wlk. (type from Borneo).

\section{Elydna sparna sp.n.}

Female.-Palpus sepia basally, pale drab-grey at extremity and inwardly. Antenna with paired setae. Head: frons pale drab-grey, tinged with sepia on upper half, vertex pale drab-grey tinged with sepia. Thorax, patagium and tegula drab-grey tinged with sepia. Abdomen drab above, venter pale drab-grey, anal tuft drab. Pectus pale drab-grey. Legs drab-grey mixed with sepia, tarsal segments sepia.__ Forewing pale drab-grey suffused with sepia, the sepia predominating in the distal half of wing ; orbicular faintly marked by pale drab-grey and sepia spot, reniform indicated by ill-defined broken outline of pale drab-grey, antemedial fascia a pale drab-grey shade, excurved, outwardly edged with sepia ; medial shade angled outwardly to upper edge of cell, then excurved to inner margin, a pale drab-grey postmedial fascia, slightly sinuous, inwardly edged with fuscous ; fringe pale drab-grey and sepia mixed, with a narrow edge of pale drab-grey ; underside light drab, irrorated with sepia below costa, faint sepia lunule on discocellulars, and postmedial fascia.—Hindwing cartridge-buff with veins streaked with light drab; underside eartridge-buff irrorated with scattered sepia scales below costa, sepia lunule on discocellulars, postmedial fascia indicated by sepia marks on veins.

Expanse $24 \mathrm{~mm}$. (Tip to tip $23 \mathrm{~mm}$.)

Holotype. Female.-Klondyke, subprov. Benguet, Luzon I., Philippines, $800 \mathrm{ft}$., 1.iv. 1912.

Nearest ally.-E. bipuncta Snell. (India, New Guinea).

\section{Phragmatiphila agrapta sp.n.}

Female.-Palpus pinkish buff, bone-brown above. Antenna minutely ciliated, with paired setae. Head: frons with rounded prominence, pinkish buff and bone-brown mixed, vertex pinkish buff and bone-brown mixed. Thorax pinkish buff, patagium pinkish buff, tegula pinkish buff with a few bone-brown scales. Abdomen drab-grey above and beneath, anal tuft wood-brown. Pectus 
pinkish buff. Legs pinkish buff, foreleg, tarsal segments bone brown, joints pinkish buff.__ Forewing pinkish buff tinged with wood-brown, lightly irrorated with scattered bone-brown scales in cell; postmedial faintly marked crenulate bone-brown line, excurved to vein 2 , then slightly incurved to inner margin, termen bone-brown; underside pinkish buff, glossy, a faint spot on discocellulars and a faint postmedial fascia.—-Hindwing: upperside cartridge-buff ; underside cartridge-buff, glossy, a faint spot on discocellulars and a very faint postmedial fascia.

Expanse $30 \mathrm{~mm}$. (Tip to tip $28 \mathrm{~mm}$.)

Holotype. Female.-Montalban, prov. Rizal, Luzon I., Philippines, 31.i. 1914.

Nearest ally.-P. grisescens Hmpsn. (India).

\section{Phragmatiphila hemicelaena sp.n.}

Male.-Palpus fuscous outwardly, pinkish buff inwardly. Antenna ciliated, with paired setae. Head: frons and vertex pinkish buff tinged with wood-brown. Thorax, patagium and tegula pinkish buff tinged with wood-brown posteriorly. Abdomen pinkish buff, some wood-brown dorsally at base, venter pinkish buff tinged with wood-brown. Pectus pinkish buff tinged with woodbrown. Legs avellaneous speckled with fuscous, fuscous on tarsal segments. Forewing pinkish buff, lightly irrorated with wood-brown along and below costa, and between veins 6 to 12 ; a cartridge-buff, wedge-shaped patch (apex basad) at base of cell up to a third, where it breaks into three lines, the upper one as far as two-thirds, the middle one a little longer, and the lower one along the median nervure to just beyond lower angle, remainder of cell filled with avellaneous tinged with wood-brown; a pinkish buff patch tinged with avellaneous near its upper edge, from just beyond cell to subterminal fascia, where it turns obliquely to apex ; below median nervure fuscous, from base gradually widening and curving upward towards end of vein 7 to termen, the area between this and inner margin pinkish buff tinged with avellaneous ; antemedial fascia faintly marked, wavy, fuscous ; postmedial fascia fuscous black, crenulate, excurved to vein 3 , then slightly incurved to inner margin ; a subterminal series of fuscous dashes, from vein 6 to inner margin, towards which they become obsolescent ; interneural fuscous black spots on termen; underside pinkish buff suffused with fuscous in cell, and half-way along veins 2 to 5 ; fuscous lunule on discocellulars, and fuscous postmedial fascia._- Hindwing pinkish buff tinged with fuscous on veins, on which there is a postmedial series of dashes; underside pinkish buff, fuscous spot on discocellulars, and fuscous postmedial fascia most strongly marked from vein 5 to inner margin, with fuscous on termen interneurally from vein 5 to inner margin.

Expanse $35 \mathrm{~mm}$. (Tip to tip $33 \mathrm{~mm}$.)

Female.-Similar to male, but is paler in colouring, and cilia of antennae shorter.

Expanse $42 \mathrm{~mm}$. (Tip to tip $40 \mathrm{~mm}$.)

Holotype. Male.-Baguio, subprov. Benguet, Luzon I., Philippines, 5,000 ft., 23. vi.1913.

Allotype. Female.-Baguio, subprov. Benguet, Luzon I., Philippines, 5,000 ft., 3. vi. 1912 . 
Paratype. Male.-Klondyke, subprov. Benguet, Luzon I., $800 \mathrm{ft} ., 16$. iii. 1912. Nearest ally.-P. nigropunctata Wileman (Formosa).

There is one specimen of this species in the Hill Museum, Witley, Surrey, which was taken in Mindanao Island, Philippine Islands.

\section{Sesamia hemisparacta sp.n.}

Male.-Palpus light buff tinged with fuscous outwardly. Antenna pectinated, pectinations ciliated. Head: frons, lower half light buff, upper half light buff tinged with wood-brown, vertex light buff tinged with wood-brown. Thorax light buff, patagium and tegula light buff with avellaneous. Abdomen light buff mixed with hair-brown, venter light buff, anal tuft pinkish buff. Pectus and legs light buff._-_Forewing light buff broadly streaked with avellaneous along and below costa, on median nervure, along inner margin and all the veins; sparsely irrorated with fuscous in cell and distal half of wing; with faint traces of a fuscous postmedial fascia parallel with termen ; underside light buff, streaked as above, but more faintly._- Hindwing light buff tinged with avellaneous, postmedial fascia indicated by scattered fuscous scales, underside light buff.

Expanse $35 \mathrm{~mm}$. (Tip to tip $33 \mathrm{~mm}$.)

Holotype. Male.-Baguio, subprov. Benguet, Luzon I., Philippines, 5, $000 \mathrm{ft}$., 16. vi. 1913.

Nearest ally.-S. punctilinea Wilem. (Formosa).

\section{SUB-FAMILY ERASTRIINAE.}

\section{Eublemma marmorata sp.n.}

Female.-Palpus cartridge-buff tinged with drab outwardly. Antenna minutely ciliated. Head : frons and vertex cartridge-buff. Thorax : patagium and tegula cartridge-buff tinged with drab. Abdomen cartridge-buff suffused with fuscous, venter cartridge-buff, anal tuft warm buff. Pectus and legs cartridge-buff._- Forewing drab, antemedially a wavy band of cartridge-buff, postmedial fascia cartridge-buff, commencing at costa as a wide band to lower angle of cell, then continuing as three incurved lines to inner margin; subterminal fascia wavy, cartridge-buff, with a series of fuscous black spots on distal edge at irregular intervals; three fuscous black spots on distal third of costa, and a larger one at apex, a few fuscous black scales on discocellulars; at middle of inner margin a fan of hair-scales. Hindwing cartridge-buff, veins and subterminal area tinged with fuscous, fringe cartridge-buff._- Underside : forewing cartridgebuff irrorated with fuscous on upper half, costa and subterminal area tinged with fuscous black; hindwing cartridge buff irrorated with fuscous below costa and on postmedial and subterminal fasciae.

Expanse, $16 \mathrm{~mm}$. (Tip to tip, $15 \mathrm{~mm}$.)

Holotype. Female.-Montalban, prov. Rizal, Luzon I., Philippines, 14.i. 1914.

Allotype. Female.-Palali, subprov. Benguet, Luzon I., Philippines, 2,000 ft., v. 1913.

Nearest ally.-E. trifasciata Moore (Bengal, India, Borneo). 


\section{Eublemma albostriata sp.n.}

Male.-Palpus pinkish buff. Antenna ciliated. Head : frons and vertex hazel. Thorax: patagium and tegula hazel tinged with liver-brown. Abdomen light drab, venter light buff. Pectus light buff. Legs light buff tinged with hazel._-Forewing hazel, antemedial fascia white, oblique to subcosta, where it is sharply angled, continuing obliquely back to inner margin; a white patch from angle of antemedial to costa joining commencement of postmedial fascia, postmedial fascia white, oblique to vein 5, where it is angled, then incurved to inner margin; a white patch irrorated with hazel at the angle of postmedial between veins 5 and 6 , reaching subterminal ; subterminal fascia zigzag, white, distally bordered with fuscous black as far as vein 5 , then faintly fuscous, wavy to inner margin, a white dash from subterminal at vein 6 to apex; hindwing: basal third cartridge buff, distal two-thirds hazel, a slightly waved white postmedial fascia from vein 6 to near tornus, a very faintly marked fuscous subterminal fascia._-Underside: forewing light buff suffused with hazel on upper half ; hindwing light buff tinged with hazel.

Expanse $18 \mathrm{~mm}$. (Tip to tip $16 \mathrm{~mm}$.)

Holotype. Male.-Klondyke, subprov. Benguet, Luzon I., Philippines, $800 \mathrm{ft}$., 13.iii. 1912.

Nearest ally.-E. rubra Hmpsn. (India, Malay, Australia).

\section{Cerynea melanocephala sp.n.}

Male.-Palpus fuscous black. Antenna ciliated, with paired setae a little longer than the cilia. Head: frons and vertex fuscous black. Thorax avellaneous, with fuscous black spot on metathorax, patagium and tegula avellaneous. Abdomen avellaneous, with a dorsal series of fuscous black spots, venter pinkish buff, anal tuft avellaneous mixed with fuscous black. Pectus pinkish buff. Legs: foreleg, coxa, femur and tibia pinkish buff with fuscous black above, tarsi pinkish buff, other legs pinkish buff.___Forewing avellaneous, lightly irrorated with fuscous black, costa warm buff, antemedially two fuscous black spots, one on costa, the other in cell ; medially three fuscous black spots, one on costa, the other two in cell; postmedial and subterminal fasciae wavy, faintly marked in a slightly paler shade than ground-colour ; a fuscous black spot postmedially between veins 5 and 6 , another fuscous black spot subterminally between veins 6 and 7 ; terminal line crenulate, fuscous black, with spot at points. Hindwing avellaneous, distal half cinnamon drab, postmedial fascia wavy, white, from vein 6 to inner margin, bordered proximally with cinnamon-drab, distally with warm buff, with fuscous black at each end; terminal line crenulate, fuscous black, with spots at points, a small fuscous black spot below middle of cell.

Underside : forewing pinkish buff tinged with fuscous black in subterminal area, a fuscous shade along and below basal half of costa, then curving and crossing wing to inner margin, distal edge crenulate; terminal line crenulate, fuscous black, with spots at points; hindwing pinkish buff, subterminal area tinged with fuscous black, fuscous lunule on discocellulars, postmedial fascia wavy, fuscous, terminal line crenulate, fuscous black, with spots at points.

Expanse $22 \mathrm{~mm}$. (Tip to tip $20 \mathrm{~mm}$.)

Holotype. Male.-Montalban, prov. Rizal, Luzon I., Philippines, 19.i.1914. Nearest ally.-C. omphisalis Wlk. (Borneo). 


\section{Oruza sordida sp.n.}

Female.-Palpus cartridge-buff mixed with fuscous. Antenna minutely ciliated, with paired setae. Head : frons and vertex cartridge-buff tinged with fuscous, occiput fuscous. Thorax: patagium and tegula cartridge-buff suffused with fuscous. Abdomen cartridge-buff suffused with fuscous above and beneath. Pectus cartridge-buff.___-Forewing cartridge-buff suffused with fuscous, eartridgebuff and fuscous marks alternately on distal half of costa, postmedial and subterminal fasciae wavy, faintly marked, proximal edge fuscous, distal edge cartridge-buff, fringe fuscous. Hindwing cartridge-buff suffused with fuscous.

Underside: forewing cartridge-buff suffused with fuscous on upper half; hindwing cartridge-buff irrorated with fuscous below costa and on subterminal area, fuscous lunule on discocellulars.

Expanse $21 \mathrm{~mm}$. (Tip to tip $19 \mathrm{~mm}$.)

Holotype. Female.-Manila, prov. Rizal, Luzon I., Philippines (plains), 7. vii. 1912.

Nearest ally.-O. atriapicata Hmpsn. (Borneo).

\section{Trogatha adusta sp.n.}

Male.-Palpus warm buff tinged with russet. Antenna ciliated. Head : frons light buff tinged with russet, vertex light buff. Thorax: patagium and tegula light buff. Pectus warm buff. Legs : coxae, femora and tibiae warm buff mixed with russet, tarsi fuscous._- Forewing, termen excised from apex to vein 4, oblique to tornus; warm buff tinged with fuscous below costa and subterminal area, irrorated with scattered fuscous black scales, lightly tinged with russet on lower half of cell ; antemedial fascia a short, excurved, fuscous streak from costa to subcosta, and four fuscous tinged russet spots; on discocellulars a faint fuscous-tinged patch with a velvety fuscous black spot at each angle of the cell, edged with fuscous proximally and distally ; postmedial fascia fuscous, oblique to vein 7 , straight to vein 3 , then slightly incurved to inner margin; subterminal fascia a broken, wavy row of fuscous spots; termen fuscous with a small patch of russet at veins 5 and 6 . Hindwing light buff, basal half lightly tinged with russet and irrorated with fuscous black below cell, postmedial fascia a wavy light buff line; distal half suffused with fuscous, russet subterminally and on termen, a light buff fringe on inner margin._-Underside : forewing warm buff suffused with russet, a suffusion of fuscous along and below costa, a drab-grey lunule outlined with fuscous black on discocellulars, a warm buff patch between the upper angle of cell and postmedial, another smaller patch between lower angle of cell and postmedial ; postmedial fascia russet from veins 8 to 5 where it is suffused with drab-grey to inner margin, a warm buff patch near apex, a border of drab-grey at termen. Hindwing warm buff, basal half tinged with russet, distal half suffused with russet, drab-grey lunule outlined with russet on discocellular, postmedial fascia russet, a border of drab-grey from postmedial to apex and along termen to tornus, light buff on inner margin, a light buff fringe on inner margin.

Expanse $23 \mathrm{~mm}$. (Tip to tip $21 \mathrm{~mm}$.)

Holotype. Male-Manila, prov. Rizal, Luzon I., Philippines (plains), 28. vii. 1912.

Nearest ally.-T. poecilota Turner (Australia, New Guinea). 


\section{Corgatha costalba sp.n.}

Male.-Palpus warm buff inwardly, wood-brown outwardly. Antenna ciliated, shaft wood-brown, white on basal third. Head: frons warm buff, vertex white. Thorax wood-brown, patagium warm buff anteriorly, wood-brown posteriorly, tegula wood-brown. Abdomen wood-brown, venter light buff, anal tuft warm buff. Pectus light buff. Legs : foreleg warm buff tinged with tawny above, other legs light buff._-_Forewing wood-brown, three white spots outlined with fuscous black on costa, subbasally, medially and postmedially; hindwing wood-brown._-Underside : fore- and hindwings light buff, lightly tinged with wood-brown, fuscous on discocellulars.

Expanse $18 \mathrm{~mm}$. (Tip to tip $17 \mathrm{~mm}$.)

Holotype. Male.-Montalban, prov. Rizal, Luzon I., Philippines, 24.iii 1914. Nearest ally.-C. pusilla Swinh. (Siam).

\section{Protarache annulata sp.n.}

Male.-Palpus fuscous, light buff beneath. Antenna serrate-ciliate. Head : frons light buff tinged with fuscous, and a round corneous plate, vertex light buff tinged with fuscous. Thorax: patagium and tegula light buff tinged with fuscous. Abdomen light buff suffused with fuscous above and beneath, anal tuft light buff. Pectus light buff. Legs light buff, mixed with fuscous above, tarsal segments fuscous, joints light buff._—_Forewing, pale drab-grey irrorated with buffy brown from base to antemedial; antemedial fascia excurved to median nervure, oblique to inner margin, pale drab-grey edged distally with buffy brown and blackish brown; area between ante- and postmedial fasciae tinged with blackish brown, a large circular patch faintly outlined with blackish brown, the proximal edge forming a prominent streak on the discocellulars ; postmedial fascia pale drab-grey excurved to vein 2, laterally to anal vein medially, then incurved to inner margin ; subterminal area light buff suffused with buffy brown, and a blackish brown streak bordering the postmedial fascia from vein 8 to 3 ; terminal line blackish brown, fringe drab grey with a fuscous line through centre ; hindwing fuscous.__ Underside : forewing fuscous with some light buff on costa near apex, termen fuscous black ; hindwing cartridge-buff irrorated with fuscous, termen fuscous black.

Expanse $20 \mathrm{~mm}$. (Tip to tip $18 \mathrm{~mm}$.)

Female.-Antenna ciliated, similar to male in colouring, but markings are more suffused, the outline of large circular patch not complete.

Expanse $24 \mathrm{~mm}$. (Tip to tip $22 \mathrm{~mm}$.)

Holotype. Male.-Klondyke, subprov. Benguet, Luzon I., Philippines, $800 \mathrm{ft} ., 20$.iv. 1912.

Allotype. Female.-Klondyke, subprov. Benguet, Luzon I., Philippines, $800 \mathrm{ft} .$, 8.v. 1912.

Nearest ally.-P. eulepida Hmpsn. (Ceylon).

\section{Trilophonota tegulata sp.n.}

Female.-Palpus fuscous, light buff inwardly. Antenna ciliated. Head : frons and vertex fuscous. Thorax: patagium and tegula fuscous. Abdomen fuscous, venter light buff, anal tuft warm buff. Pectus light buff. Legs light buff tinged with fuscous, tarsal segments fuscous, joints light buff._- Forewing 
pale drab-grey dusted over with fuscous, all fasciae wavy, fuscous; a fuscous shade medially, fringe drab-grey tinged with fuscous; orbicular and reniform faintly outlined with fuscous ; hindwing fuscous, fuscous black termen, and some fuscous black at tornus, fringe drab-grey tinged with fuscous.—-Underside, foreand hindwings pale drab-grey suffused with fuscous.

Expanse $18 \mathrm{~mm}$. (Tip to tip $17 \mathrm{~mm}$.)

Male.-Similar to female, but paler in colouring.

Expanse $18 \mathrm{~mm}$. (Tip to tip $17 \mathrm{~mm}$.)

Holotype. Female.-Klondyke, subprov. Benguet, Luzon I., Philippines, $800 \mathrm{ft} .$, 8.v. 1914.

Allotype. Male.-Baguio, subprov. Benguet, Luzon, 5,000 ft., 30.v.1913.

The female is selected for the holotype, the male being imperfect, as the head is missing.

Nearest ally.-T. lamia Swinh. (Burma).

\section{Hyperstrotia variata sp.n.}

Male.-Palpus light buff mixed with fuscous. Antenna ciliated. Head: frons light buff with a band of fuscous just below the bases of antennae, vertex light buff. Thorax : patagium and tegula light buff tinged with warm sepia, tuft of fuscous black on metathorax. Abdomen light buff suffused with fuscous above and beneath, anal tuft warm buff. Pectus light buff tinged with fuscous. Legs : fore- and midlegs light buff suffused with fuscous, tarsal segments fuscous, joints light buff, hindleg light buff lightly tinged with fuscous.-_- Forewing : light buff patch at base, its distal edge oblique from costa subbasally to median nervure antemedially, here sharply angled, then oblique to inner margin subbasally, at this point a scale-tooth on inner margin ; area from this patch to postmedial light buff suffused with warm sepia, in which is the antemedial fascia, wavy, light buff and fuscous black faintly marked, also a light buff dash on anal vein from antemedial ; postmedial fascia oblique to inner margin near tornus, light buff at ends, white in middle, from the white part of postmedial there is a white streak to apex ; area below this streak light buff tinged with warm sepia, above light buff tinged with warm sepia in streaks ; hindwing cartridge-buff._- Underside: forewing cartridge-buff tinged with fuscous; hindwing cartridge-buff irrorated with fuscous below costa, fuscous spot on discocellulars.

Expanse $20 \mathrm{~mm}$. (Tip to tip $19 \mathrm{~mm}$.)

Female.-Similar to male.

Expanse $21 \mathrm{~mm}$. (Tip to tip $20 \mathrm{~mm}$.)

This species appears to be extremely variable: of the nine specimens before us five are typical, the other four not having the white streak at apex; some do not have the dark patch across the middle of wing, some have it only on upper half of wing, in one case the forewing is plain with fuscous black dashes. Paratypes marked thus $\left({ }^{*}\right)$ are typical.

Holotype. Male.-Baguio, subprov. Benguet, Luzon I., Philippines, 5,000 ft., 24.iv. 1912.

Allotype. Female.-Baguio, subprov. Benguet, Luzon I., Philippines, 5, $000 \mathrm{ft}$., 28.v. 1913.

*Paratype. Male-Baguio, subprov. Benguet, Luzon I., Philippines, 5,000 ft., 20.v. 1913. 
*Paratype. Male.-Baguio, suibprov. Benguet, Luzon I., Philippines, $5,000 \mathrm{ft} ., 27 . \mathrm{iv} .1912$.

*Paratype. Male.-Baguio, subprov. Benguet, Luzon I., Philippines, $5,000 \mathrm{ft} ., 22$.iv. 1912.

Paratype. Male.-Baguio, subprov. Benguet,Luzon I., Philippines, 5,000 ft., v. 1913.

Paratype. Male.-Baguio, subprov. Benguet, Luzon I., Philippines, 5,000 ft., 26.iv. 1912.

Paratype. Male.-Baguio, subprov. Benguet, Luzon I., Philippines, $5,000 \mathrm{ft}$., 2.vi. 1913.

Paratype. Female.-Baguio, subprov. Benguet, Luzon I., Philippines, $5,000 \mathrm{ft}$., $26 . \mathrm{v} .1912$.

Nearest ally. $-H$. macroplaga Hmpsn. (Ceylon).

\section{SUBFAMILY SARROTHRIPINAE.}

\section{Characoma casuaria sp.n.}

Male.-Palpus: second segment pale drab-grey, basal half fuscous, third segment pale drab-grey speckled with fuscous. Antenna (description impossible as both are missing in the type). Head: frons pale drab-grey, vertex pale drab-grey tinged with blackish brown. Thorax: patagium and tegula pale drab-grey suffused with blackish brown. Abdomen pale drab-grey tinged with fuscous, venter and anal tuft pale drab-grey. Pectus pale drab-grey. Legs: foreleg pale drab-grey tinged with warm sepia above on tibia and on tarsal segments, other legs pale drab-grey._- Forewing: pale drab-grey tinged dark greyish brown, subbasal fascia, fuscous black, wavy to median fold ; antemedial fascia consisting of two, wavy, fuscous black lines, bordered by a shading of warm sepia to just below cell; medially a wide band tinged with dark greyish brown, edged with fuscous black, the proximal edge wavy, bordered by pale drab-grey, the distal edge oblique to vein 6 , outwardly angled, then inwardly angled, oblique to vein 4, sharply excurved and oblique to vein 2 , excurved to inner margin, a shading of warm sepia beyond; subterminal fascia wavy, dark greyish brown, bordered with pale drab-grey, termen fuscous black, fringe pale drab-grey tinged with fuscous. Hindwing pale drab-grey tinged with fuscous on termen, fringe pale drab-grey._-Underside: forewing fuscous, with three pale drab-grey points on costa near apex, fringe pale drab-grey; hindwing pale drab-grey tinged with fuscous below costa and on termen.

Expanse $22 \mathrm{~mm}$. (Tip to tip $21 \mathrm{~mm}$.)

Holotype. Male.-Haight's Place, Pauai, subprov. Benguet, Luzon I. Philippine Is., 7,000 ft., 1.xii. 1912.

Nearest ally. - C. vallata Meyr. (Australia).

The medial band resembles somewhat the head of a cassowary.

\section{Characoma latifascia sp.n.}

Female.-Palpus pinkish buff tinged with fuscous above. Antenna minutely ciliated, with paired setae. Head: frons and vertex pinkish buff tinged with fuscous. Thorax: patagium and tegula fuscous. Abdomen pinkish buff suffused with fuscous, venter and anal tuft pinkish buff. Pectus light buff. 
Legs: foreleg pinkish buff tinged with fuscous, other legs pinkish buff. Forewing fuscous with a purple tinge ; antemedial fascia a fine mars-brown line, oblique to subcosta, slightly incurved to median fold, oblique to inner margin; a triangular pale drab-grey patch on costa, the base of triangle touching the antemedial and the apex touching the postmedial on costa, orbicular a small pale drab-grey spot, reniform indicated by two fuscous black dots; postmedial fascia consisting of two fine mars-brown lines, excurved to vein 2 , then slightly incurved to inner margin : a pale drab-grey dash at apex, subterminal fascia a shading of mars-brown. Hindwing cartridge-buff tinged with fuscous.-Underside : fore- and hindwings cartridge-buff tinged with fuscous, glossy.

Expanse $20 \mathrm{~mm}$. (Tip to tip $19 \mathrm{~mm}$.)

Holotype. Female.-Klondyke, subprov. Benguet, Luzon I., Philippine Is., $800 \mathrm{ft}$., 10 .iii.1912.

Nearest ally. - C. vallata Meyr. (Australia).

\section{Sarrothripus glaucus sp.n.}

Female.-Palpus white, lightly tinged with fuscous. Antenna minutely ciliated, with paired setae. Head: frons cartridge-buff, vertex olive buff. Thorax: patagium olive-buff with a fuscous black line through centre, tegula olive-buff. Abdomen (description impossible as it is missing from the type). Pectus cartridge-buff. Legs : fore- and midlegs cartridge-buff, with olive-buff above, hindleg cartridge-buff._—_Forewing : cartridge-buff, suffused with olivebuff, all fasciae and markings fuscous black, subbasal fascia wavy, antemedial fascia consisting of two broken, wavy lines ; a patch in distal half of cell ; postmedial fascia a broken line, oblique to vein 6 , outwardly angled and oblique to vein 2, incurved to inner margin ; a small patch on costa beyond postmedial ; subterminal fascia a wavy line of dots, interneural spots on termen. Hindwing cartridge-buff, lightly tinged with fuscous in subterminal area and on veins._Underside : forewing cartridge-buff, tinged with fuscous; hindwing cartridgebuff, tinged with fuscous below costa and on veins.

Expanse $22 \mathrm{~mm}$. (Tip to tip $21 \mathrm{~mm}$.)

Holotype. Female.-Klondyke, subprov. Benguet, Luzon I., Philippine Is., $800 \mathrm{ft}$., 12 .iv. 1912.

Nearest ally. $-S$. indica Feld. (Ceylon, Singapore, Australia).

\section{Sarrothripus albescens sp.n.}

Male.-Palpus white, with a little fuscous above. Antenna ciliated, with paired setae. Head : frons and vertex white. Thorax : patagium and tegula fuscous. Abdomen fuscous, venter pale drab-grey. Pectus white. Legs: foreleg white with fuscous above, other legs white.-_-Forewing: white; subbasal fascia fuscous black, wavy, to median nervure; medially a wide fascia outlined with fuscous, bordered distally with a narrow white line, commencing with a triangular, fuscous patch on costa (apex distad), the remainder of fascia lightly tinged with fuscous, the proximal edge wavy, the distal edge inwardly oblique to vein 7 , excurved to vein 5 , again excurved to vein 2 , then incurved to inner margin, where the fascia is half the width it is at costa ; area beyond tinged with fuscous, in which is a wavy, white, subterminal fascia, termen fuscous black with interneural points, fringe white. Hindwing white, tinged with fuscous 
on termen.-- Underside : fore- and hindwings glossy, pale drab-grey tinged with fuscous, fringe pale drab-grey.

Expanse $18 \mathrm{~mm}$. (Tip to tip $17 \mathrm{~mm}$.)

Holotype. Male.-Klondyke, subprov. Benguet, Luzon I., Philippine Is., $800 \mathrm{ft} ., 6$.iv. 1912 .

Nearest ally. - S. exophila Meyr. (Australia).

\section{Barasa nigrilineata sp.n.}

Male.-Palpus cartridge-buff mixed with vinaceous on first segment, cartridge-buff with fuscous at base of second and third segments. Antenna minutely eiliated, with paired setae. Head : frons white mixed with vinaceous, a lateral, fuscous black spot, vertex white mixed with vinaceous. Thorax: patagium and tegula white speckled with fuscous. Abdomen fuscous with white at junction of segments, a fuscous and white tuft at base dorsally, venter white. Pectus white. Legs : foreleg, coxa white tinged with vinaceous, femora and tibia white tinged with vinaceous, fuscous above, tarsus fuscous ; midleg white speckled with vinaceous on tibia, fuscous on basal segment of tarsus; hindleg white, fuscous on tarsus beneath._- Forewing white, a fuscous patch on costa at base, outlined with fuseous black, basal third of wing irrorated with fuscous ; medially a wide fascia tinged with fuscous bordered by a narrow white line, proximal edge outwardly oblique to subcosta, incurved to median fold, incurved to inner margin, distal edge incurved to vein 7 , excurved to vein 5 , excurved to vein 2, excurved to inner margin, with a fuscous black spot where it crosses vein 2 ; reniform indicated by a very small warm sepia spot; subterminal area tinged with fuscous in which there is an almost straight, fuscous black fascia, edged with warm sepia, and a small fuscous spot tinged with warm sepia at apex. Hindwing white, slightly opalescent, with fuscous on costa and termen, gradually decreasing in width toward tornus._-Underside : forewing fuscous; hindwing same as upperside.

Expanse $26 \mathrm{~mm}$. (Tip to tip $24 \mathrm{~mm}$.)

Holotype. Male.-Montalban, prov. Rizal, Luzon I., Philippine Is., 21.i.1914.

Nearest ally.-B. tetragramma Hmpsn. (Fiji).

\section{Risoba ornata sp.n.}

Male.-Palpus pinkish buff with livid brown outwardly. Antenna fasciculate. Head : frons pinkish buff, a lateral livid brown spot, vertex pinkish buff. Thorax : patagium pinkish buff mixed with tawny, tegula pinkish buff. Abdomen pinkish buff above and beneath, a small tuft at base dorsally tipped with tawny, anal tuft pinkish buff tinged with tawny. Pectus pinkish buff. Legs : foreleg pinkish buff with blackish brown above, tarsal segments blackish brown, pinkish buff at joints, other legs pinkish buff, tarsal segments blackish brown, pinkish buff at joints._—_Forewing eartridge-buff, tinged with dark olive-buff along costa, tinged with pinkish cinnamon in and below cell, a bone-brown patch subbasally from costa to subcosta where it is bent outwardly ; medially a shaded bone-brown mark outwardly oblique, from apex to inner margin ; an oblique white streak, wide at commencement, gradually narrowing and becoming tinged with pinkish cinnamon near inner margin ; area beyond olive-buff tinged 
with bone-brown near apex, suffused with pinkish cinnamon between veins 3 and 6 , below vein 3 tinged with bone-brown, in which is a white patch on inner margin near tornus; postmedial fascia bone-brown, crenulate, incomplete (points distad), a white spot on each point on veins 2 to 6 , interneural bone-brown spots on termen. Hindwing light-buff, with a tinge of livid brown in subterminal area, fringe light buff._- Underside : forewing light buff on costa, termen and inner margin, remainder tinged with livid brown ; hindwing light buff irrorated with livid brown below costa and on subterminal area.

Expanse $32 \mathrm{~mm}$. (Tip to tip $31 \mathrm{~mm}$.)

Holotype. Male.-Sapiangao, subprov. Benguet, Luzon I., Philippine Is., $5,600 \mathrm{ft} ., 16$. xii. 1918.

Paratype. Male.-Haight's Place, Pauai, subprov. Benguet, Luzon I., Philippine Is., 7,000 ft., 8.xi. 1912.

Nearest ally. $-R$. basalis Moore (India, Ceylon, Singapore, Formosa).

\section{SUBFAMILY WESTERMANNIINAE.}

\section{Aiteta olivana sp.n.}

Male.-Palpus brownish olive, light buff beneath at base. Antenna ciliated, with paired setae. Head : frons and vertex brownish olive. Thorax : patagium and tegula brownish olive. Abdomen fuscous, venter and anal tuft cartridgebuff. Pectus cartridge-buff. Legs light-buff speckled with fuscous above, tarsal segments fuscous above, cartridge-buff at joints._- Forewing : upper half light buff tinged with avellaneous, lower half blackish brown tinged with brownish olive; a large brownish olive, almost semicircular patch, edged with a narrow line of cartridge-buff, occupying the central third of costa, and extending downward to the anal vein, in the centre of patch the reniform is indicated by a blackish brown spot; subterminal area tinged with blackish brown, in which is a fascia of brownish olive, outwardly oblique to vein 6 , then wavy to termen. Hindwing cartridge-buff, blackish brown below costa, on subterminal area and on veins.-Underside: forewing fuscous, avellaneous on costa, cartridge-buff at base, tinged with brownish olive in cell, avellaneous near apex; hindwing cartridge-buff, blackish brown below costa, on subterminal area, and on veins.

Expanse $38 \mathrm{~mm}$. (Tip to tip $36 \mathrm{~mm}$.)

Female.-Similar to male, but paler in colouring.

Expanse $38 \mathrm{~mm}$. (Tip to tip $36 \mathrm{~mm}$.)

Holotype. Male.-Haight's Place, Pauai, subprov. Benguet, Luzon I., Philippine Is., 7,000 ft., 12.i.1912.

Allotype. Female.-Baguio, subprov. Benguet, Luzon I., Philippine Is., $5,000 \mathrm{ft} ., 10 . v i .1913$.

Nearest ally.-A. trigoniphora Hmpsn. (Assam).

\section{Carea subvia sp.n.}

Male.-Palpus cinnamon-brown, tinged with vinaceous russet. Antenna bifasciculate. Head: frons and vertex cinnamon-brown. Thorax: patagium cinnamon-brown, tegula cinnamon-brown tinged with vinaceous russet. Abdomen vinaceous russet above and beneath, with a patch of fuscous at base dorsally, bordered laterally with cartridge-buff, anal tuft warm buff. Pectus cartridge- 
buff tinged with vinaceous russet. Legs : foreleg vinaceous russet, with cartridgebuff above on tibia and tarsus, midleg inwardly cartridge-buff, outwardly vinaceous russet, mixed with fuscous on tibia, hindleg cartridge-buff tinged with vinaceous russet, a long tuft of warm-buff and cartridge-buff hairs from the inside of tibia, just below femur.—Forewing cinnamon-brown with a shading of pale drab-grey medially ; an outwardly oblique cinnamon-brown fascia, bordered by pale drab-grey proximally, from costa antemedially to inner margin medially ; postmedial fascia cinnamon-brown, bordered distally by pale drab-grey, outwardly oblique to vein 6 , where it is bent, and only slightly oblique to inner margin ; subterminal fascia a series of fuscous black dots, a shading of fuscous black at apex, fringe fuscous black edged with vinaceous russet. Hindwing vinaceous russet with fuscous hair-scales along inner margin.-Underside: forewing vinaceous russet, a fuscous black patch at apex; hindwing cartridge-buff, vinaceous russet on upper half, irrorated with fuscous black near apex.

Expanse $40 \mathrm{~mm}$. (Tip to tip $38 \mathrm{~mm}$.)

Female.-Similar to male, but deeper in colouring, the forewing almost a blackish brown.

Expanse $40 \mathrm{~mm}$. (Tip to tip $38 \mathrm{~mm}$.)

Holotype. Male.-Haight's Place, Pauai, subprov. Benguet, Luzon I., Philippine Is., 7,000 ft., 30.vi.1913.

Allotype. Female.-Haight's Place, Pauai, subprov. Benguet, Luzon I., Philippine Is., 7,000 ft., 26. vii. 1913.

Paratype. Female.-Haight's Place, Pauai, subprov. Benguet, Luzon I., Philippine Is., 7,000 ft., 27. vii. 1913.

Nearest ally.-C. obvia Hmpsn. (Philippines).

\section{Carea carissima sp.n.}

Female.-Palpus liver-brown. Antenna minutely biciliated. Head : frons with a smooth corneous plate, bone-brown above, vertex bone-brown. Thorax : patagium bone-brown, tegula pallid vinaceous drab, a patch of warm buff edged with bone-brown and a small tuft of white each side on metathorax. Abdomen pallid vinaceous drab tinged with liver-brown, a white tuft at base dorsally, venter and anal tuft white. Pectus white. Legs white inwardly, liver-brown outwardly, an oblique band of white round centre of tibiae, and at junction with tarsi, all tarsal segments liver-brown, white at joints._- Forewing pallid vinaceous drab; subbasal fascia a wide shade of vinaceous brown, slightly excurved from costa to median fold; area below cell, between subbasal and antemedial fasciae vinaceous brown ; antemedial fascia vinaceous brown, bordered by pallid vinaceous drab, incurved to subcosta, incurved to median nervure, excurved to anal vein, excurved to inner margin; orbicular a blackish brown spot, reniform a blackish brown lunule, surrounded by a tinge of warm buff; area from antemedial to just beyond postmedial fasciae vinaceous brown; postmedial fascia blackish brown, bordered distally by pale drab-grey the same width as fascia, straight to subcosta, excurved to vein 5 , incurved to vein 4 , two small incurves to vein 2, angled and longitudinal, again angled and outwarelly oblique to inner margin; subterminal area pallid vinaceous drab, subterminal fascia blackish brown, in two short excurves, then straight to tornus, bordered proximally with white, termen blackish brown. Hindwing: cartridge-buff tinged with liver-brown near apex, on veins and termen.-Underside: fore- 
wing white tinged with liver-brown, two white patches on costa; hindwing white irrorated with liver-brown below costa on basal half, termen liver-brown.

Expanse $32 \mathrm{~mm}$. (Tip to tip $30 \mathrm{~mm}$.)

Holotype. Female.-Kolambugan, subprov. Lanao, Mindanao I., Philippine Is. (plains), 21.vi.1914.

Nearest ally.-C. albopurpurea Hmpsn. (Assam).

\section{Orthocraspis rectitermen sp.n.}

Female.-Palpus cartridge-buff mixed with fuscous. Antenna minutely biciliated, with paired setae. Head : frons and vertex light buff, with a fuscous black tuft projecting forward between the bases of antennae. Thorax : patagium and tegula light buff, with a few fuscous black specks. Abdomen light buff, venter cartridge-buff. Pectus cartridge-buff. Legs: foreleg cartridge-buff with fuscous above and outwardly, other legs cartridge-buff.-—Forewing: light buff tinged with fuscous, with a few scattered fuscous black specks; three light buff longitudinal stripes, occupying the width of the wing, the upper one, from costa just before middle, slightly down-curved to near termen ; the middle one, from costa at base, not curved as much as the upper one, to near middle of termen ; the lower one straight from base to near tornus. Hindwing cartridgebuff, tinged fuscous along termen and inne: margin.--Underside: forewing cartridge-buff, with a fuscous streak below costa, and a fuscous spot on discocellulars, another near apex; hindwing cartridge-buff, irrorated with fuscous, a fuscous spot on discocellulars, another near apex.

Expanse $34 \mathrm{~mm}$. (Tip to tip $32 \mathrm{~mm}$.)

The paratype is larger and has, in addition to other markings, a prominent fuscous-black spot on discocellulars of fore wing.

Expanse $36 \mathrm{~mm}$. (Tip to tip $35 \mathrm{~mm}$.)

Holotype. Female.-Baguio, subprov. Benguet, Luzon I., Philippine Is., $5,000 \mathrm{ft} ., 18$. iii. 1912 .

Paratype. Female.-Baguio, subprov. Benguet, Luzon I., Philippine Is., $5,000 \mathrm{ft} ., 3 . x i .1912$.

Nearest ally.-O. acypera Hmpsn. (Bali, Philippines).

\section{SubFamily CATOCALINAE.}

\section{Anophiodes pulchrilinea sp.n.}

Female.-Palpus mars-brown, fuscous at base of second segment Antenna minutely ciliated, with paired setae. Head: frons and vertex mars-brown. Thorax: patagium blackish brown edged with mars-brown, tegula blackish brown mixed with mars-brown. Abdomen light buff, lightly tinged with fuscous above and beneath, anal tuft warm buff. Pectus fuscous. Legs : foreleg fuscous, tibia mars-brown, other legs fuscous, all tarsal segments blackish brown, light buff at joints._-Forewing: mars-brown, overlaid with blackish-brown, subbasal fascia blackish brown, bordered with russet, wavy to median fold ; antemedial fascia blackish brown, bordered with russet, outwardly oblique to subcosta, inwardly oblique to median nervure, excurved to anal vein, again excurved to inner margin; orbicular indicated by a blackish brown spot surrounded by russet, reniform stigma russet, surrounded by a narrow blackish brown line, 
outlined with light buff, two blackish brown rings below reniform, the one between median nervure and vein 2, the other between vein 2 and anal vein; postmedial fascia consisting of two blackish brown lines, in a large excurve to anal vein, then excurved to inner margin, where there is a speck of white ; subterminal fascia light buff bordered proximally by a band of russet, which commences below apex, crosses fascia at vein 7 , touching fascia to just below vein 2 , where it separates and is slightly curved inwards; a longitudinal streak of russet from reniform to subterminal fascia, two patches of russet and light buff on termen, the one near apex, the other between veins 3 and 4 . Hindwing white, tinged with fuscous at base and on inner margin, fuscous on subterminal area, a white patch in centre, white on termen near apex and near tornus.-Underside : forewing white, suffused with fuscous, a band of white across the middle of wing edged with fuscous proximally, a cartridge-buff subterminal fascia and two patches of cartridge-buff on termen; hindwing: basal half white, tinged with fuscous below costa, distal half fuscous, white in centre, and on termen near apex and tornus.

Expanse 44. (Tip to tip $42 \mathrm{~mm}$.)

Holotype. Female.-Haight's Place, Pauai, subprov. Benguet, Luzon I., Philippine Is., 7,000 ft., 1.xii.1912.

Paratypes. Female.-Haight's Place, Pauai, subprov. Benguet, Luzon I., Philippine Is., 7,000 ft., 29.xi. and 8.xii. 1912.

Nearest ally.-A. meeki Beth.-Baker (New Guinea).

\section{SubFamily DIPHTHERINAE.}

\section{Elydnodes ornata sp.n.}

Male.-Palpus light-buff, with blackish brown above. Antenna bifasciculate. Head : frons and vertex light buff. Thorax : patagium and tegula light buff, tinged with sepia. Abdomen light-buff above and beneath. Pectus light buff. Legs : foreleg light buff, tinged with dark greyish olive, other legs light buff, with hairs on tibiae tinged with dark greyish olive.--Forewing: cartridgebuff at base, subbasal fascia blackish brown, proximal edge straight, sharply defined, distal edge suffused into ground-colour, from the upper half a streak to costa antemedially, from the lower half a wide shade of dark greyish olive on inner margin to about one half ; antemedial fascia a narrow blackish brown line, bordered proximally by cartridge-buff, distally by a suffusion of greyish olive and dark greyish olive, inwardly oblique from subcosta to median nervure, angled and outwardly oblique to inner margin ; orbicular sepia stigma outlined with cartridge-buff and blackish brown, reniform a sepia lunule outlined proximally with cartridge-buff and blackish brown touching orbicular, distally by light buff; ; medially a blackish brown shade; from apex an oblique line to inner margin at about a third, the first half a clearly defined division between two colours, the second half a fuscous shade, above this line a long cartridge-buff patch from reniform to apex, the upper edge suffused with greyish olive, below this line the postmedial fascia commences, a blackish brown, crenulate, excurved line (points distad), joining antemedial fascia on inner margin ; at commencement of postmedial fascia two sepia dashes tinged with blackish brown to near termen bordered distally with light buff; a suffusion of sepia on termen just below apex, cartridge-buff on veins 3 to 6 . Hindwing light-buff suffused with 
warm buff, tinged with fuscous in subterminal area._-Underside: forewing light buff, a blackish brown patch in distal half of cell, surrounded by a tinge of sepia, postmedial fascia faintly marked, termen tinged with sepia, with white points at ends of veins ; hindwing light buff, a blackish brown patch on discocellulars, postmedial fascia blackish brown faintly marked.

Expanse $36 \mathrm{~mm}$. (Tip to tip $34 \mathrm{~mm}$.)

Holotype. Male.-Klondyke, subprov. Benguet, Luzon I., Philippine Is., $800 \mathrm{ft} ., 17$.iv. 1912.

Paratype. Male.-Klondyke, subprov. Benguet, Luzon I., Philippine Is., $800 \mathrm{ft} ., 6$. iv.1912.

Nearest ally.-E. variegata Leech (China).

\section{SUBFAMILY PHYTOMETRINAE.}

\section{Phytometra luzonensis sp.n.}

Female.-Palpus light buff tinged with warm sepia. Antenna minutely ciliated, with paired setae. Head : frons and vertex light buff tinged with warm sepia, with a small white tuft at base of each antenna, occiput light buff. Thorax : patagium warm sepia, with a band of blackish brown across centre, narrowly edged with white posteriorly, tegula warm sepia. Abdomen warm sepia, with a fuscous tuft at base dorsally, venter light buff mixed with warm sepia. Pectus warm buff. Legs clothed with blackish brown scales and hair-scales tipped with white, tarsal segments fuscous, white at joints._- Forewing warm sepia tinged with blackish brown, which in certain lights has a metallic bronze sheen ; subbasal fascia a wavy, brassy-metallic line, antemedial fascia consisting of two wavy, brassy-metallic lines; below distal half of cell two silver spots with a brassy-metallic edge, the proximal one nearly U-shaped, the distal one circular ; a suffusion of blackish brown beyond cell; postmedially a wavy sepia shade followed by a long white patch reaching from costa to vein 3 , in which is a wavy, warm sepia line nearest the proximal edge; subterminal fascia wavy, blackish brown defined by white, which, between veins 5 and 6 , forms a wedge of white in fascia ; terminal line sepia, interneural blackish-brown spots on termen, fringe white and blackish brown mixed. Hindwing fuscous._Underside: foreand hindwings cartridge-buff tinged with fuscous on basal half, suffused with fuscous on distal half.

Expanse $36 \mathrm{~mm}$. (Tip to tip $34 \mathrm{~mm}$.)

Holotype. Female.-Haight's Place, Pauai, subprov. Benguet, Luzon I., Philippine Is., 7,000 ft., 25.vi. 1913.

Nearest ally.-P. chalcytes Esper (Europe, Asia, Australia, Polynesia).

\section{SUBFAMILY OPHIDERINAE. ${ }^{1}$}

\section{Belciana bicolor sp.n.}

Male.-Palpus fuscous. Antenna minutely ciliated. Head: frons upper half mytho-green, lower half fuscous, vertex fuscous, occiput whitish. Thorax : patagium fuscous, edged with mytho-green posteriorly, tegula mytho-green, fuscous anteriorly. Abdomen cartridge-buff tinged with fuscous above and beneath, a patch of mytho-green at base dorsally, anal tuft fuscous. Pectus 
cartridge-buff. Legs cartridge-buff tinged with fuscous, mytho-green on foretibia, tarsal segments fuscous, cartridge-buff at joints.-Forewing whitish, overlaid with mytho-green, subbasally a fuscous patch on costa, narrowing and angled at median nervure, inwardly oblique to anal vein ; antemedial fascia a wavy fuscous line; medially, on costa a triangular fuscous patch, the point just below subcosta, from which is a fascia, excurved to vein 2 , excurved to anal vein, excurved to inner margin; postmedial fascia fuscous, wavy to vein 3 , inwardly oblique to vein 2, slightly excurved to inner margin ; a large fuscous patch at apex, and a small one at tornus, interneural fuscous spots on termen. Hindwing cartridge-buff tinged with fuscous at base, suffused with fuscous on distal half._-Underside : forewing cartridge-buff tinged with fuscous on upper half, postmedial fascia fuscous, ill-defined, subterminal area suffused with fuscous ; hindwing cartridge-buff tinged with fuscous, postmedial and subterminal fasciae fuscous, fuscous lunule on discocellulars.

Expanse $34 \mathrm{~mm}$. (Tip to tip $33 \mathrm{~mm}$.)

Female.-Similar to male.

Expanse $43 \mathrm{~mm}$. (Tip to tip $41 \mathrm{~mm}$.)

Holotype. Male.-Kolambugan, subprov. Lanao, Mindanao I., Philippine Is. (plains), 25.v. 1914.

Allotype. Female.-Kolambugan, subprov. Lanao, Mindanao I., Philippine Is. (plains), 29.v. 1914.

Nearest ally.-B. biformis Wlk. (Singapore, Borneo).

\section{Catephia philippinensis sp.n.}

Female.-Palpus fuscous-black, cartridge-buff below and at joints. Antenna minutely ciliated, with paired setae. Head: frons and vertex cartridge-buff tinged with fuscous, a fuscous band below the bases of antennae. Thorax: patagium and tegula cartridge-buff tinged with fuscous, a large tuft of fuscous on metathorax. Abdomen fuscous with dorsal crests, venter light buff, anal tuft light buff tinged with fuscous. Pectus light-buff. Legs : fore- and midlegs light buff mixed with fuscous, tarsal segments fuscous black, light buff at joints ; hindleg light buff, tarsal segments fuscous black, light buff at joints._Forewing fuscous, subbasal fascia blackish brown, wavy to anal vein ; antemedial fascia blackish brown, wavy, ill-defined ; orbicular a small light buff spot outlined with blackish brown; reniform a white oblique stigma tinged with fuscous on proximal edge, a suffusion of white, forming a band from costa medially, downcurved, passing reniform, to termen at veins 3 and 4 ; postmedial fascia an illdefined, excurved, crenulate, blackish brown line ; subterminal fascia a cartridgebuff, wavy line, a small white spot near tornus, interneural blackish brown spots on termen. Hindwing: basal half white, distal half fuscous, white on fringe just below apex and near tornus._-Underside: forewing, basal third white tinged with fuscous, a white band across centre, distal third fuscous, white on termen; hindwing similar.

Expanse $26 \mathrm{~mm}$. (Tip to tip $25 \mathrm{~mm}$.)

Holotype. Female.-Klondyke, subprov. Benguet, Luzon I., Philippine Is., $800 \mathrm{ft} ., 11$.iii. 1912.

Paratypes. Females.-Klondyke, subprov. Benguet, Luzon I., Philippine Is., $800 \mathrm{ft}$., 15. and 22. iii. 1912.

Nearest ally.-C. sciachroa Hmpsn. (Ceylon, Philippines). 
This species appears to be variable, the area below the cell, between the ante- and postmedial fasciae in one instance, is much darker than in the others, forming a blackish brown patch.

Neogabara gen. nov.

Proboscis fully developed; palpus obliquely upturned, the second segment not reaching vertex of head, thickly scaled and dilated at extremity, third segment short and thickly scaled; frons smooth; eye large, round; antenna of female ciliated, with paired setae ; thorax clothed almost entirely with scales and without crests; the tibiae smoothly scaled; abdomen with a dorsal crest at base only. Forewing with the termen evenly curved and not crenulate; a series of scale-teeth on inner margin ; vein 3 from near angle of cell ; 4, 5 from angle ; 6 from upper angle ; 9 from 10 anastomosing with 8 to form the areole ; 7 from beyond the areole; 11 from cell. Hindwing with the cell two-thirds the length of wing ; veins 3,4 from angle ; 5 fully developed from well above angle ; 6,7 shortly stalked; 8 anastomosing with the cell near base only.

Genotype: Neogabara plagiola sp.n.

Having found it impossible to fit this species into any of the existing genera, we have erected the genus Neogabara. It is closely allied to Paragabara Hmpsn., which, however, has the palpus reaching the vertex of head, the forefemora of male with a tuft of curved hair at extremity, the midtibia dilated with a fold containing a tuft of long hair, veins 3 and 5 of forewing near angle of cell, 6 and 7 of hindwing from upper angle.

\section{Neogabara plagiola sp.n.}

Female.-Palpus cartridge-buff inwardly, wood-brown outwardly. Antenna minutely ciliated, with paired setae. Head: frons and vertex wood-brown. Thorax: patagium and tegula wood-brown. Abdomen wood-brown, venter cartridge-buff. Pectus cartridge-buff. Legs cartridge-buff, wood-brown outwardly, fuscous on tarsal segments.—Forewing wood-brown irrorated with blackish brown and dark purple-drab, giving the wing a purple sheen in certain lights ; antemedial fascia russet, slightly wavy, with a white spot on proximal edge below median nervure ; postmedial fascia a russet line edged distally with blackish brown, slightly excurved to vein 6 , oblique to inner margin, with two white spots on distal edge, a small one above vein 2, a larger, triangular one, below vein 2 ; termen russet with interneural blackish brown spots. Hindwing fuscous._-Underside : fore- and hindwings cartridge-buff tinged with fuscous.

Expanse $26 \mathrm{~mm}$. (Tip to tip $24 \mathrm{~mm}$.)

Holotype. Female.-Kolambugan, subprov. Lanao, Mindanao I., Philippine Is. (plains), 21.vi.1914.

\section{Oglasa incurvata sp.n.}

Female.-Palpus fuscous, drab-grey at tip. Antenna minutely ciliated. Head: frons drab-grey and bone-brown mixed, vertex drab-grey speckled with bone-brown. Thorax: patagium drab-grey speckled with bone-brown, edged inwardly with bone-brown forming a median line, tegula drab-grey. Abdomen drab-grey tinged with fuscous above and beneath. Pectus drab-grey. Legs drab-grey tinged with fuscous.—-Forewing drab-grey irrorated with bone- 
brown, antemedial fascia a fine bone-brown line, commencing with a small patch on costa, incurved to subcosta, excurved to anal vein, excurved to inner margin ; medially on costa a triangular bone-brown patch, the point touching an elongate blackish brown patch in distal half of cell, from the distal edge of triangular patch, a fine bone-brown line, excurved round the distal end of blackish brown patch, then incurved to inner margin ; postmedial fascia a fine bone-brown line, outwardly oblique to vein 6 , angled and inwardly oblique to vein 5 , excurved to vein 2 , incurved to inner margin ; beyond postmedial on costa, a semicireular bone-brown patch, with three drab-grey points on costa, a small bone-brown spot near costa, a suffusion of fuscous in subterminal area, interneural bone-brown spots on termen. Hindwing drab-grey, suffused with fuscous.-Underside : forewing drab-grey, suffused with fuscous, with drab-grey on costa near apex, antemedial and postmedial fasciae faintly marked; hindwing drab-grey, irrorated with fuscous below costa and on subterminal area, antemedial and postmedial fasciae faintly marked.

Expanse $26 \mathrm{~mm}$. (Tip to tip $25 \mathrm{~mm}$.)

Holotype. Female.-Klondyke, subprov. Benguet, Luzon I., Philippine Is., $800 \mathrm{ft} ., 16 . \mathrm{v} .1912$.

Nearest ally.-O. captata Butl. (India).

\section{Oglasa contigua sp.n.}

Female.-Palpus cartridge-buff, fuscous black on second segment outwardly and above. Antenna minutely ciliated, with paired setae. Head: frons and vertex cartridge-buff. Thorax: patagium and tegula light buff tinged with pale ochraceous buff. Abdomen pale ochraceous buff above and beneath, anal tuft warm buff. Pectus cartridge-buff. Legs : fore and midlegs cartridge-buff, with fuscous on tibiae outwardly, hindleg cartridge-buff, tinged with pale ochraceous buff, all tarsal segments fuscous, cartridge-buff at joints.

Forewing: pale ochraceous buff, two small fuscous black spots on costa, one at base, the other antemedially; two triangular fuscous black patches on costa, with the apex produced and bent outwardly, one medially, the other subterminally; a patch of fuscous and fuscous black on the middle third of inner margin followed by white, the upper edge being just above the anal vein ; reniform faintly outlined with fuscous and defined by cartridge-buff; from the apex of subterminal patch on costa, a wavy fascia of fuscous bordered by white ; interneural spots of fuscous preceded by white on termen. Hindwing cartridgebuff tinged with fuscous near apex.—-Underside: forewing cartridge-buff, tinged with fuscous; hindwing cartridge-buff, irrorated with fuscous below costa and at apex.

Expanse $31 \mathrm{~mm}$. (Tip to tip $30 \mathrm{~mm}$.)

Holotype. Female.-Montalban, prov. Rizal, Luzon I., Philippine Is., 14.iv. 1914.

Nearest ally.-O. separata Wlk. (India).

\section{Plecoptera costinotata sp.n.}

Female.-Palpus pinkish buff. Antenna minutely ciliated, with paired setae. Head: frons and vertex pinkish buff, tinged with ochraceous orange. Thorax : patagium pinkish buff, tinged with ochraceous orange, tegula pinkish- 
buff. Abdomen light buff above and beneath, anal tuft pinkish buff. Pectus light-buff. Legs pinkish buff.___Forewing pinkish buff, a fuscous patch in cell at distal end, with a fuscous suffusion above reaching to costa, increasing to twice the width of patch at costa, the suffusion more strongly marked on the edges. Hindwing cartridge-buff, postmedial fascia a fine, faintly marked, fuscous line ; a faint fuscous border subterminally.—-Underside: forewing light buff, a faint fuscous spot on discocellulars, and a fuscous fascia subterminally from vein 6 to near tornus; hindwing light buff, a faint fuscous spot on discocellulars, a faintly marked postmedial fascia.

Expanse $26 \mathrm{~mm}$. (Tip to tip $25 \mathrm{~mm}$.)

Holotype. Female.-Klondyke, subprov, Benguet, Luzon I., Philippine Is., $1,300 \mathrm{ft} ., 23 . x \mathrm{ii} .1911$.

Nearest ally.-P. flava Brem. (China, Assam, India). 


\section{$2 \mathrm{BHL}$ Biodiversity Heritage Library}

Wileman, A. E. and West, R. J. 1929. "Description of new species of Noctuidae." Novitates zoologicae : a journal of zoology in connection with the Tring Museum 35, 1-27. https://doi.org/10.5962/bhl.part.10813.

View This Item Online: https://www.biodiversitylibrary.org/item/22617

DOI: https://doi.org/10.5962/bhl.part.10813

Permalink: https://www.biodiversitylibrary.org/partpdf/10813

\section{Holding Institution}

Natural History Museum Library, London

\section{Sponsored by}

Natural History Museum Library, London

\section{Copyright \& Reuse}

Copyright Status: In copyright. Digitized with the permission of the rights holder.

Rights Holder: The Trustees of the Natural History Museum, London

License: http://creativecommons.org/licenses/by-nc-sa/4.0/

Rights: http://biodiversitylibrary.org/permissions

This document was created from content at the Biodiversity Heritage Library, the world's largest open access digital library for biodiversity literature and archives. Visit BHL at https://www.biodiversitylibrary.org. 